\title{
Severe malnutrition after bariatric surgery and clinic manifestations of infection
}

\author{
(iD) Alice Avesani Cavotto Furlan ${ }^{1}$ \\ Marcia Varella Morandi Junqueira-Franco ${ }^{1}$ \\ (iD) Joyce Cristina Santos de Oliveira ${ }^{1}$ \\ (iD) José Wilson de Souza Favaris ${ }^{1}$ \\ (iD) Julio Sérgio Marchini ${ }^{1}$ \\ Selma Freire Carvalho Cunha ${ }^{1}$
}

1. Divisão de Nutrologia do Departamento de Clínica Médica, Faculdade de Medicina de Ribeirão Preto, Universidade de São Paulo, Ribeirão Preto, São Paulo, Brasil.

http://dx.doi.org/10.1590/1806-9282.65.9.1151

\section{SUMMARY}

This report describes the post-bariatric-surgery evolution of an obese patient who had low adherence to the diet and micronutrient supplementation. Four years after two bariatric surgeries, the patient was admitted due to transient loss of consciousness, slow thinking, anasarca, severe hypoalbuminemia, in addition to vitamin and mineral deficiencies. She had subcutaneous foot abscess but did not present fever. Received antibiotics, vitamins A, D, B12, thiamine, calcium, and parenteral nutrition. After hospitalization (twenty-eight days), there was a significant body weight reduction probably due to the disappearance of clinical anasarca. Parenteral nutrition was suspended after twenty-five days, and the oral diet was kept fractional. After hospitalization (weekly outpatient care), there was a gradual laboratory data improvement, which was now close to the reference values. Such outcome shows the need for specialized care in preventing and treating nutritional complications after bariatric surgeries as well as clinical manifestations of infection in previously undernourished patients.

KEYWORDS: Obesity. Bariatric surgery. Protein Deficiency. Avitaminosis. Mineral Deficiency.

\section{INTRODUCTION}

Obesity is defined as the excessive accumulation of body fat and classified based on a body mass index (BMI) above $30 \mathrm{~kg} / \mathrm{m}^{2}$. Its treatment involves a dietary approach, the practice of physical activities and, under specific conditions, the use of medication. When these therapeutic measures fail, bariatric surgery is an alternative to control and treat obesity. ${ }^{1}$

Bariatric treatment of obesity involves the reduction of the size of the stomach, besides intestinal shutting to reduce nutrient absorption. ${ }^{2}$ In comparison to changes in lifestyle, behavior and pharmacological intervention, bariatric surgery is more effective in promoting weight loss, thus resulting in the clinical improvement of comorbidities associated with obesity. ${ }^{3}$ Although it presents a low mortality rate, bariatric surgery increases the risk of surgical, metabolic, and nutritional complications. ${ }^{1}$ In this report, we discuss a case of multiple combined nutritional deficiencies and atypical clinical manifestations of infection in the late postoperative period of bariatric surgery.

\section{CASE PRESENTATION}

This case was conducted in a public teaching hospital. The local Research Ethics Committee was notified, and informed consent from the patient was obtained. 
A 39-year-old woman was hospitalized for 28 days. She stayed in the emergency unit for two days and remained in the medical nutrition ward for the rest of the period.

Her weight before her first pregnancy (21 years ago) was $50 \mathrm{~kg}$; after that, she gained weight, reaching $180 \mathrm{~kg}\left(\mathrm{BMI}=69 \mathrm{~kg} / \mathrm{m}^{2}\right)$. Four years before the admission to our service, she was submitted to bariatric surgery. At that time, the Duodenal Switch procedure was performed, a restrictive and malabsorptive technique. ${ }^{4}$ She lost $50 \mathrm{~kg}$, and her weight stabilized at $130 \mathrm{~kg}$. She did not do physical exercise and did not adhere to the diet prescribed. One year before admission to our center, she underwent another bariatric surgery with an additional weight loss of $40 \mathrm{~kg}$. There was no information about this more recent procedure, although the patient reported further intestinal resection. Since the first surgery, the patient maintained four liquid evacuations per day, without steatorrhea and food debris present in the feces. Two months before admission, the number of evacuations increased to 20 , without mucus or blood. During this short period, the patient lost $24 \mathrm{~kg}$.

The patient was admitted due to a transient loss of consciousness. She complained of edema in the lower limbs, weakness, and dizziness, with worsening of symptoms two weeks before hospitalization. At admission, she was $84 \mathrm{~kg}$ and $162 \mathrm{~cm}$ tall, BMI of $32 \mathrm{~kg} / \mathrm{m}^{2}$. She had discolored mucous membranes, slow thinking, confused speech, and no fever. Physical examination showed brittle nails, alopecia, angular cheilitis, and tongue papillary atrophy. There were no cardiac abnormalities, but the lungs were congested. She presented severe peripheral edema and ascites. The dorsal surface of the right foot presented swelling and fluctuation, with spontaneous drainage of purulent material, without local blush or heat.

\section{INVESTIGATIONS}

The patient denied ingesting alcoholic beverages. Her usual diet showed high intakes of meat and soft drinks and low intake of fruit, vegetables, milk, cheese, and yogurt. She reported a hypercaloric $(2600 \mathrm{kcal} /$ day) and high-protein ( $97 \mathrm{~g} /$ day) diet, and the intake of calcium and vitamins B12, C, A, E, and acid folic were below the nutritional recommendations. ${ }^{5} \mathrm{We}$ measured the body weight regularly and analyzed the total body water by bioelectrical impedance (Biodynamics BIA 450 Analyzer, Biodynamics Corporation, Shoreline, WA, USA) (Figure 1).

The electroencephalogram (EEG) and cranial tomography were normal. The patient presented negative serology for HIV and typical serum values of hepatic transaminases, urea, and creatinine. There was a marked reduction in the serum values of hemoglobin, total protein, albumin, transferrin, and an increase in reactive C-protein (Table 1). The 24-hour urine collection did not show proteinuria. The lipid profile and the ultrasound of the liver were normal. Low blood levels of vitamin A, iron, copper, magnesium, phosphorus, and calcium were also detected. Simple chest radiography presented signs of pulmonary edema. The barium enema examination evidenced a

FIGURE 1. BODYWEIGHT AND BODY WATER EVOLUTION DURING ADMISSION, ANALYZED BY BIOELECTRICAL IMPEDANCE.

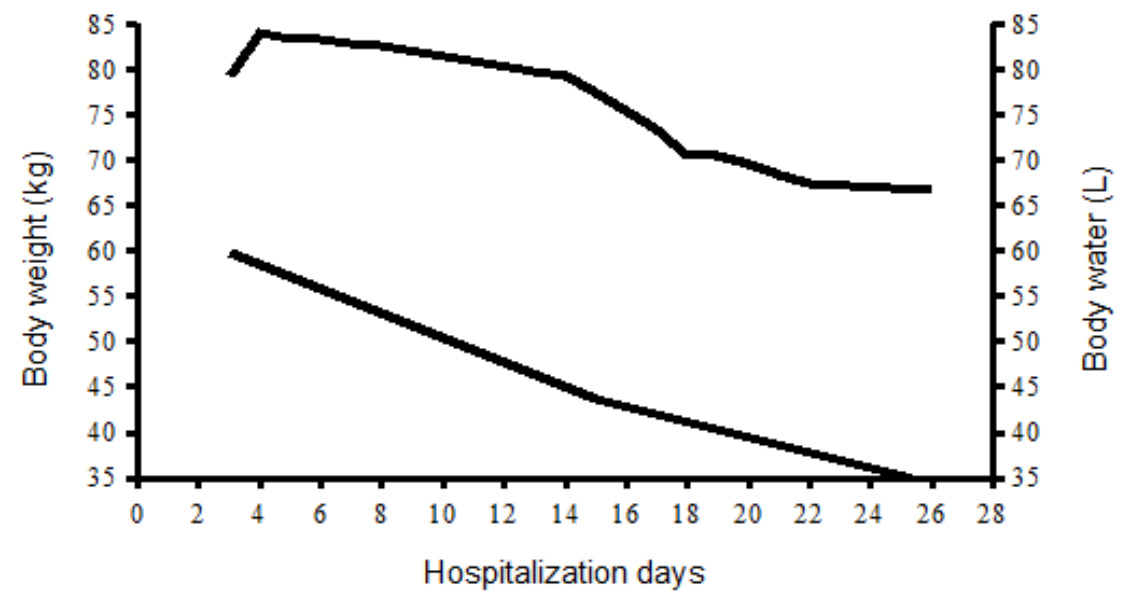

Body weight $(\mathrm{kg})$ Body water $(\mathrm{L})$ 
small gastric segment, reduced ileal and cecal loops compatible with short bowel syndrome, besides an enlargement of the lumen and increased intestinal villus in the distal portion (Figure 2). Exudate from the foot's lesion showed the growth of Streptococcus $\mathrm{sp}$, sensitive to ciprofloxacin and clindamycin.

\section{TREATMENT}

The patient received an oral diet and intravenous antibiotics on the first day of inpatient care. The following morning, the patient became apathetic and unresponsive to verbal stimuli. The electroencephalogram and the computerized tomography brain were normal. At the time, the patient was given nil by mouth status and did not receive artificial nutrition, enterally or parenterally. The patient received intramuscular vitamin B12 and intravenous vitamin B1 and iron. There were partial improvements in memory and speech patterns.

On the third hospitalization day, the patient still presented anasarca and diarrhea. Intravenous albumin was not administered. Parenteral nutrition by central venous access was prescribed with $600 \mathrm{kcal}$ per day, with a progressive increase to $1800 \mathrm{kcal}$ and $1.5 \mathrm{~g}$ of protein/kg on the $12^{\text {th }}$ day. The status of nil by mouth was maintained until the fifth day, when she started receiving liquid orally. Afterward, the diet was fractionated into six meals, fiber-restricted, without lactose and sucrose. The patient received red blood cell transfusions on the $10^{\text {th }}$ day. We did not measure thiamine serum levels, but the patient received high quantities of thiamine (300 mg/day) for three days during the beginning of parenteral nutrition because of the high risk of the refeeding syndrome. Apart from the vitamin and mineral content in the parenteral nutrition, the patient received an extra amount of oral vitamin D (2000 IU/day), vitamin A (5000 IU/ week), and calcium (500 mg, 12/12h) for 13 days. She received loperamide $(2 \mathrm{mg} /$ day $)$ during all hospital stay. After 25 days of receiving parenteral nutrition, the therapy was suspended, and the patient was kept only on an oral diet.

\section{OUTCOME AND FOLLOW-UP}

During hospitalization, there was a progressive bodyweight reduction (18.4 kg), attributed to fluid loss $(25.3 \mathrm{~kg})$, with the anasarca elimination. The patient was discharged from the hospital with stable vital signs, and conscious. Her specialized oral diet with dietary recommendations included $1300 \mathrm{kcal}$ and $62 \mathrm{~g}$ of protein/day, in addition to oral mineral and vitamin supplementation. Outpatient follow-up was weekly in the first month and monthly after that. Bodyweight remained relatively stabilized without any fluid retention, and there were improvements in the laboratory data (table 1).

\section{DISCUSSION}

This case report describes a patient who developed clinical and laboratory findings of vitamin and mineral deficiencies, severe protein malnutrition, and an infectious condition in the late postoperative of bariatric surgery. It is likely that the patient presented multiple subclinical nutritional deficiencies for an extended period, due to the poor quality of food intake and to

FIGURE 2. RADIOGRAPHIC IMAGE OF THE CHEST AND BARIUM ENEMA STUDY,
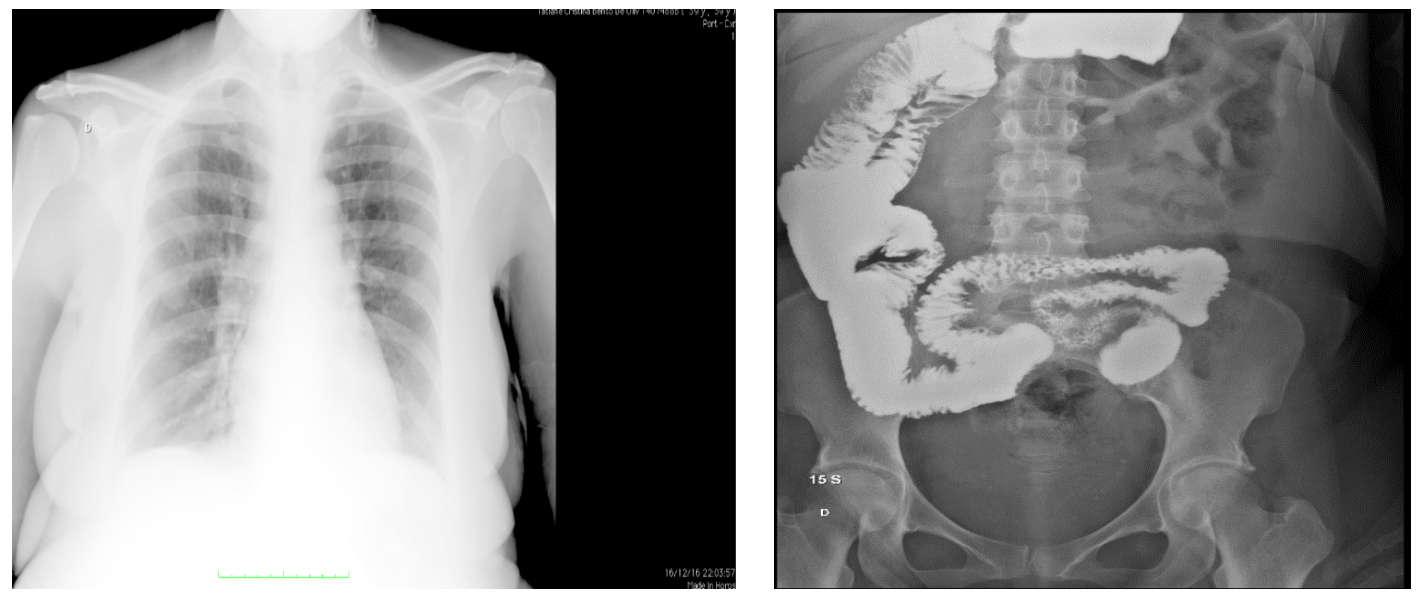
TABLE 1. HEMATOLOGIC AND BLOOD BIOCHEMICAL DATA AT THE MOMENT OF ADMISSION, DISCHARGE (28 DAYS AFTER ADMISSION), AND IN OUTPATIENT CARE (6O DAYS AFTER DISCHARGE).

\begin{tabular}{|c|c|c|c|c|}
\hline & \multicolumn{2}{|c|}{ Hospitalization } & \multirow[t]{2}{*}{ Outpatient care } & \multirow[t]{2}{*}{ Reference values } \\
\hline & Admission & Discharge & & \\
\hline Blood fasting glucose (mg/dL) & 95 & 100 & - & $70-100$ \\
\hline Urea (mg/dL) & 37 & 20 & 21 & $10-50$ \\
\hline Creatinine (mg/dL) & 0.73 & 0.74 & 0.64 & $0.7-1.6$ \\
\hline Aspartate aminotransferase (U/L) & 21 & 17.3 & 17.8 & $<32$ \\
\hline Alanine aminotransferase $(\mathrm{U} / \mathrm{L})$ & 19 & 15 & 17.2 & $<31$ \\
\hline Alkaline phosphatase (U/L) & 264 & 138 & 185 & $65-300$ \\
\hline$\gamma$-glutamyl transferase $(U / L)$ & 55 & 71 & 25 & $11-50$ \\
\hline C-reactive protein $(\mathrm{mg} / \mathrm{dL})$ & 7.85 & 2.32 & - & $<0.5$ \\
\hline Ferritin (ng/mL) & - & 123 & 70 & $6-159$ \\
\hline Hemoglobin (g/dL) & 5.9 & 8.7 & 11.7 & $12.4-16.1$ \\
\hline Mean corpuscular volume (fL) & 94 & 91 & 97 & $80.1-95.3$ \\
\hline Leukocytes $(103 / \mu \mathrm{L})$ & 7.3 & 4.6 & 5.4 & $4.05-11.8$ \\
\hline Neutrophils $(103 / \mu \mathrm{L})$ & 5.3 & 2.6 & - & $1.2-7.2$ \\
\hline Lymphocytes $(103 / \mu \mathrm{L})$ & 1.6 & 1.5 & 1.5 & $900-2900$ \\
\hline Total protein (g/dL) & 4.4 & 5.6 & 5.9 & $6.0-8.0$ \\
\hline Albumin (g/dL) & 1.5 & 2.8 & 3.4 & $3.5-4.8$ \\
\hline Transferrin (mg/dL) & 10.6 & 162 & 150 & $>170$ \\
\hline Vitamin B12 (pg/mL) & - & $>1000$ & 934 & $174-878$ \\
\hline Folic acid (ng/mL) & - & 9 & 14 & $>5.9$ \\
\hline Vitamin A (mg/L) & 0.2 & 0.4 & 0.3 & $0.3-0.7$ \\
\hline Vitamin E (mg/L) & 5.0 & 6.2 & 4.7 & $5-20$ \\
\hline Vitamin D (ng/mL) & - & - & 14.8 & $20-50$ \\
\hline Iron $(\mu \mathrm{g} / \mathrm{dL})$ & 30 & 29 & 53 & $50-170$ \\
\hline Copper ( $\mu g / d L)$ & 39.4 & - & 79 & $85.0-155.0$ \\
\hline Total calcium (mg/dL) & 7.0 & 8.6 & 8.9 & $8.4-10.5$ \\
\hline
\end{tabular}

chronic diarrhea, secondary to an intestinal failure. ${ }^{6}$

Duodenal Switch reduces the absorption of approximately $25 \%$ of protein, and $72 \%$ of fat ingested. ${ }^{7}$ Although there was no information about the second intestinal resection, most likely, this late procedure contributed to the aggravation of nutrient malabsorption. On the other hand, the barium enema showed that there were some adaptive changes to the remaining small intestine, as it occurs in the late postoperative in short bowel syndrome. ${ }^{8}$

The patient presented manifestations of protein malnutrition like alopecia, anemia, water and electrolytic imbalance, severe hypoalbuminemia and anasarca. ${ }^{9}$ Hypoalbuminemia occurs in $13 \%$ of patients after two months and approximately $30 \%$ in ten years after bariatric surgery. ${ }^{10}$ In this report, hypoalbuminemia can be partially ascribed to intestinal malabsorption, but not to low protein intake, liver disease, or renal protein loss. Protein malnutrition can lead to the atrophy of the intestinal villus and decrease in digestive enzymes, thus aggravating diarrhea. In its turn, diarrhea aggravates the hypoalbuminemia, thus creating a vicious cycle.
The patient presented infection by Streptococcus sp in a subcutaneous abscess in the foot, which may have possibly induced an acute phase response. This hypothesis is in agreement with the increase in reactive C-protein, the marked reduction in serum albumin, and fluid retention. In the acute phase response, there is an increase in protein catabolism, hepatic synthesis of acute-phase reactants at the expense of albumin, and capillary leakage of albumin into the interstitial space. ${ }^{11}$ Patients with protein and micronutrient deficiencies present an elevated risk to develop infections due to the deterioration of immune response and the frailty of biological barriers. ${ }^{12}$ In malnourished people, an infection can cause atypical neurologic manifestations, the absence of fever, and no alterations in white blood cell count or signs of inflammatory processes, ${ }^{13}$ which is compatible with our findings.

Bariatric surgery leads to deficiencies of iron, vitamin B1, vitamin B12, folic acid, vitamin D, and calcium, preventable by a multi-professional approach during the postoperative period. ${ }^{14}$ However, low adherence to postoperative follow-up often occurs, since patients feel well and pleased with the weight loss. Besides, 
nutritional deficiencies can be asymptomatic, and when symptoms appear, the micro and macronutrient storages are already severely diminished. ${ }^{15}$

We did not measure vitamin B12 and folic acid before the patient received parenteral supplementation at our hospital. She presented vitamin A deficiency due to low vitamin absorption. The reduced absorption of this vitamin seems to be the cause of hypovitaminosis A. However, we cannot rule out the possibility of a systemic inflammatory response reducing the hepatic synthesis of transporting proteins for that vitamin, ${ }^{16}$ which seems to be an epiphenomenon of acute-phase response. ${ }^{17}$

\section{CONCLUSION}

The patient who underwent bariatric surgery presented protein malnutrition that was aggravated by worsening diarrhea and the development of a subcutaneous abscess. In addition to the correct use of antibiotics, there was a need for parenteral nutrition until absorptive capacity was recovered. This report illustrates the need for specialized follow-up aimed at the prevention of nutritional complications in patients undergoing bariatric surgery. Besides, patients with multiple nutritional deficiencies may present atypical clinical manifestations of infection.

\section{RESUMO}

Este relato descreve a evolução pós-cirurgia bariátrica de uma paciente obesa que apresentou baixa adesão à dieta e suplementação de micronutrientes. Quatro anos após duas cirurgias bariátricas, a paciente foi internada por perda transitória de consciência, raciocínio lento, anasarca, hipoalbuminemia grave, além de deficiências vitamínicas e minerais. Apresentava abscesso subcutâneo no pé, mas não apresentava febre. Recebeu antibióticos, vitaminas A, D, B12, tiamina, cálcio e nutrição parenteral. Após a internação (28 dias) houve redução significativa do peso corporal, provavelmente devido ao desaparecimento clínico da anasarca. A nutrição parenteral foi suspensa após 25 dias e a dieta oral foi mantida fracionada. Após a internação (atendimento ambulatorial semanal) houve uma melhora gradativa dos dados laboratoriais, que estavam próximos dos valores de referência. Tal desfecho mostra a necessidade de cuidados especializados na prevenção e tratamento de complicações nutricionais após cirurgias bariátricas, bem como manifestações clínicas de infecção em pacientes previamente desnutridos.

PALAVRAS-ChaVE: Obesidade. Cirurgia bariátrica. Deficiência de proteína. Deficiência de vitaminas. Deficiência de minerais.

\section{REFERENCES}

1. Heymsfield SB, Wadden TA. Mechanisms, pathophysiology, and management of obesity. N Engl | Med. 2017;376(3):254-66.

2. Kreykes $A$, Choxi $H$, Rothberg A. Post-bariatric surgery patients: your role in their long-term care. J Fam Pract. 2017;66(6):356-63.

3. Pinhel MA, Nicoletti CF, Oliveira BA, Chaves RC, Parreiras LT, Sivieri T, et al. Weight loss and metabolic outcomes 12 months after roux-en-y gastric bypass in a population of southeastern Brazil. Nutr Hosp. 2015;32(3):1017-21.

4. Bennett JM, Mehta S, Rhodes M. Surgery for morbid obesity. Postgrad Med J. 2007;83(975):8-15.

5. Institute of Medicine (US) Subcommittee on Interpretation and Uses of Dietary Reference Intakes; Institute of Medicine (US) Standing Committee on the Scientific Evaluation of Dietary Reference Intakes. DRI dietary reference intakes: applications in dietary assessment. Washington: National Academies Press; 2000.

6. Nicoletti CF, Lima TP, Donadelli SP, Salgado Jr W, Marchini JS, Nonino CB. New look at nutritional care for obese patient candidates for bariatric surgery. Surg Obes Relat Dis. 2013;9(4):520-5.

7. Topart P, Becouarn G, Delarue J. Weight loss and nutritional outcomes 10 years after biliopancreatic diversion with duodenal switch. Obes Surg. 2017;27(7):1645-50.

8. Chagas-Neto FA, Barreto ARF, Muglia VF, Elias Junior J, Bellucci AD, Marchini IS, et al. Barium follow through in the assessment and follow-up of adult patients with short bowel syndrome. Radiol Bras. 2011;44(3):188-91.
9. Martins TC, Duarte TC, Mosca ER, Pinheiro CF, Marçola MA, De-Souza $D A$. Severe protein malnutrition in a morbidly obese patient after bariatric surgery. Nutrition. 2015;31(3):535-8.

10. Taton N, Borel AL, Chobert Bakouline M, Fauconnier J, Arvieux C, Reche F. Malnutrition after bariatric surgery. Minerva Chir. 2017;72(6):464-74.

11. Cunha DF, Monteiro IP, Santos VM, Oliveira FA, Cunha SFC. Hyponatremia in acute-phase response syndrome patients in general surgical wards. Am | Nephrol. 2000;20(1):37-41.

12. Scrimshaw NS, SanGiovanni JP. Synergism of nutrition, infection, and immunity: an overview. Am | Clin Nutr. 1997;66(2):464S-77.

13. Cunha SFC, Parada AO, Araújo GT. Abordagem clínica e nutricional do paciente subnutrido. In: Vannucchi H, Marchini IS, eds. Manual de procedimentos em nutrologia. Rio de Janeiro: Guanabara Koogan; 2009. p.329-42.

14. Donadelli SP, Junqueira-Franco MV, Mattos Donadelli CA, Salgado Jr W, Ceneviva R, Marchini JS, et al. Daily vitamin supplementation and hypovitaminosis after obesity surgery. Nutrition. 2012;28(4):391-6.

15. Santarpia L, Grandone I, Alfonsi L, Sodo M, Contaldo F, Pasanisi F. Longterm medical complications after malabsorptive procedures: effects of a late clinical nutritional intervention. Nutrition. 2014;30(11-12):1301-5.

16. Stephensen CB, Gildengorin $G$. Serum retinol, the acute phase response, and the apparent misclassification of vitamin A status in the third National Health and Nutrition Examination Survey. Am J Clin Nutr. 2000;72(5):1170-8.

17. Barbosa KC, Cunha DF, Jordão AA |r, Weffort VR, Cunha SF. Transient decreased retinol serum levels in children with pneumonia and acute phase response. J Pediatr (Rio J). 2011;87(5):457-60. 